\title{
Station Rotation Type Blended Learning Model Against Critical Thinking Ability of Fourth Grade Students
}

\author{
Dewa Made Dwicky Putra Nugraha \\ Pendidikan Guru Sekolah Dasar, Universitas Dwijendra, Indonesia \\ email: madedwicky@undwi.ac.id
}

\author{
A R T I C L E I N F O \\ Article history: \\ 1 Agustus 2020 Received in \\ revised form \\ 20 September 2020 \\ Accepted 10 November 2020 \\ Available online 20 \\ November 2020 \\ Kata Kunci. \\ Blended Learning, Station \\ Rotation \\ Keywords: \\ Blended Learning, Station \\ Rotation, Critical Thinking \\ Skill
} menggunakan pembelajaran konvensional, sehingga dapat disimpulkan bahwa penerapan model blended learning tipe station rotation berpengaruh positif terhadap kemampuan berpikir kritis siswa kelas IV SD.

\section{A B S T R A C T}

This study is conducted based on the problem of the low critical thinking skills of grade 4th students of SDK Karya Singaraja. It is presumed because the learning model applied is less relevant to the students' need. The model that expected can solve the problem is the blended learning station rotation model. This study investigates critical thinking difference between students with blended learning rotation models and students with conventional learning toward fourth-grade students of SDK Karya Singaraja. The instrument of data collection is a critical thinking skill test in the form of an essay. The data is analyzed descriptively. The hypothesis is tested by using t-test polled variance. The study results show that the experiment group's mean score is 81,28 and higher than the control group, 65,5. Meanwhile, it gains score tvalue $(5,21)>\operatorname{ttable}(2,00)$ with 5\% significant $(0,05)$. The result shows a significant difference between students with blended learning rotation models and students with conventional learning. It can be concluded that the blended learning rotation model positively affects the critical thinking of the fourth-grade students of SDK Karya Singaraja. Appropriate learning model selection affects students' critical thinking.

\section{Introduction}

One of the important skills for the formation of a qualified individual is the ability to think critically. The ability to think critically is the ability to analyze and evaluate the thinking process (Surya, 2011). The process of critical thinking or criticizing something is classified as a high-order way of thinking. An individual is said to have good critical power when seeing phenomena from a deeper and specific perspective. This way of thinking will help someone anticipate and overcome various problems that may arise. Critical thinking can also be the basis for decision-making. Critical thinking skills must be built from an early age. Education, especially at the primary school level, is very important to encourage children's critical thinking skills. A person's critical thinking ability can be seen in giving opinions confidently and acting by giving reasons (Mabruroh \& Suhandi, 2017). A child's critical thinking ability can help him reason and digest all information logically. Ennis (in Susanto, 2015) mentioned that critical thinking helps children decide what to believe and use logic. Reasoning with logic bridges the process of understanding a concept or phenomenon. Educators in elementary schools need to create a learning atmosphere that can activate students' critical thinking processes (Jaya, 2017).

Open and critical thinking patterns will significantly assist children in gaining more meaningful knowledge. The ability to think critically can stimulate students' cognitive reasoning in gaining experience and solving given problems (Crismono, 2017; Jupriyanto, 2018; Marfilinda et al., 2019). During the learning process, students will be able to develop ideas about problems in learning. With the ability to think critically, students will be able to review issues with a wider dimension. This ability is beneficial for a student (Setyaningsih et al., 2014; 
Syarifah \& Sumardi, 2015). In the short term, students will be trained to find ideas in every problem they encounter in learning. Meanwhile, in the long term, students will have the ability to accumulate all possible solutions to problems more accurately. Efforts to strengthen critical thinking skills should be started from elementary school age.

The distribution of students who show critical thinking skills in class is not much. The lack of student activity in the learning process is the main indication. The activity of asking questions or analyzing the correctness of information while studying is almost challenging to find. The low level of thinking activity ultimately leads to less than optimal learning outcomes. This problem was also found in fourth grade SDK Karya Singaraja. Based on the interviews with homeroom teachers, the critical thinking skills of 56 fourth-grade students tended to be less than optimal. The teacher illustrates this according to several indications. The lack of student activity in learning is the main indication. (2018) Teachers must find ways to be active in learning to improve students' critical thinking skills, for example, by using interesting media, reading student characteristics, and finding the causes of student learning difficulties.

However, what was found in grade IV SDK Karya Singaraja, is still far from that. Based on the description above, it can be specified several main issues regarding the low critical thinking skills of students, among others; 1) low student learning activities, in the sense that students tend to be passive in learning, 2) management of internet-based learning activities is not effective, and 3) learning activities are not developed that strengthen the use of online media in learning, so that freedom of thought and openness of information is minimal. From these findings, it can be drawn a root problem that triggers the problem of students' critical thinking skills is the applied learning model. According to Simanjuntak \& Sudibjo (2019), learning must make students think actively and openly so that they get used to solving existing problems. In addition, student-centered learning will make students more active and more independent in discovering their knowledge. An effective learning process will make students active during the learning process (Usman, 2019). To improve critical thinking skills, a learning model must be chosen that makes students active and open to various information and knowledge.

The learning model that is considered capable of anticipating these problems is the blended learning model. Blended learning combines all learning forms, such as online or face-to-face learning (Ningsih et al., 2017; Suartama, 2014). Elementary school-age children's learning characteristics are related to physical activity, generally like moving or practicing directly (Burhaein, 2017). The type of blended learning chosen is the station rotation type, looking at elementary school students' learning characteristics who tend to be physically active. The blended learning station rotation type allows students to visit several stations or centers repeatedly and non-linearly during the specified time for certain subject matter. The syntax or learning steps in the station rotation type blended learning model proposed by Widyaningsih et al. (2020) include; 1) class setting and preparing learning tools, 2) organizing students, forming groups according to the desired number of stations, 3) providing introductory material and learning activities at each station, 4) learning at each station such as discussion, reading, drawing, coloring, observing, role-playing, learning online, making posters, and writing stories, 5) rotating or moving stations, 6) presenting learning outcomes at all stations, and 7) collective reflection.

Pedagogically, the blended learning model can encourage creating an active, learner-centered learning atmosphere and good interaction in the learning process (Blankson et al., 2014). The process of digesting information does occur not only formally but also informally. Students who take the Blended learning program are proven to have significant reading test results. Besides, this learning approach can expand the benefits of technology in learning. The learning time used is more effective than ordinary learning (Prescott et al., 2018). Blended learning is also believed to have grown from better planning and using the internet comprehensively and effectively (Banggur et al., 2018). This model is also predicted to have a positive impact on students' critical thinking skills. It is because this model can create an active, independent, and problem-solving learning atmosphere. Especially with the demands of the technology era like today, learning is expected to accommodate students' obtaining information from various sources, including the internet. In addition to adding insight, this step can stimulate students to use open thinking to improve their critical thinking skills.

The application of the station rotation of blended learning model in elementary schools is still unfamiliar because blended learning is generally more widely applied at higher education levels (Drysdale et al., 2013). This model can be used as an alternative in overcoming student learning boredom in elementary schools. The combination of direct (face-to-face) learning with learning through the use of the internet (online) is a learning approach that can accommodate student learning needs. Anggraeni,dkk (2019), found that students who were taught using blended learning techniques received more information than students who were only taught using conventional models, affecting their critical thinking skills. Syarif (2013) shows a significant increase in student motivation and achievement due to applying the blended learning model. Research conducted by Novia Anggraini dan Wayan Suana (2018) states that the application of Schoology-based blended learning has a significant effect on critical thinking skills. The relevant research results reinforce the notion that the blended learning model is very relevant to overcome students' low thinking skills. 
The research objective was to analyze the differences in critical thinking skills between students who took the station rotation blended learning model and students who took the conventional learning model in fourth-grade elementary school students. The use of the station rotation type of blended learning model is expected to accommodate the learning styles of elementary school children who tend to be psychomotor active.

\section{Method}

This study analyses the differences in critical thinking skills between students who take the station rotation blended learning model and students who take conventional learning models in fourth-grade elementary school students. Therefore the type of research used is quasi-experimental research (Quasi Experiment) with a nonequivalent control group design. According to Sugiono (2015), the non-equivalent control group design compared the control and experimental groups. In this study, the subject's condition was accepted as it was not randomly grouping the subjects. The population in this study were all fourth-grade students of SDK by Singaraja. The population in this study was 56 people. This study's sample distribution was class V A as an experimental group consisting of 28 children and class V B as a control group consisting of 28 children. The research sample was selected using the purposive sampling technique by considering the problems, class conditions, and students' numbers. Judging from the existing problems, the two-sample groups have the same problem in critical thinking skills. Judging from the condition of supporting infrastructure, the two groups have classrooms of almost the same size, with almost the same media and learning resources. The number of children from each sample group was also the same, making it easier for researchers to determine samples and analyze data.

There are two variable characteristics in this study, one independent variable, and one dependent variable. This study's independent variable is a blended learning model with the station rotation type. The dependent variable in this study is the students' critical thinking ability. Thus the analytical design used is the t-test. The research data collected is data on thematic learning outcomes on the theme of My ideals. This study's data collection technique was a test technique in an essay test in a story question. The essay test used was valid in terms of content and items. It was reliable based on the prerequisite test of the instrument. The essay test questions used consisted of 5 items with a weighted score of 5 . The essay test provided contained several learning contents, mathematics (2 questions), Indonesian (1 question), Science (1 question), and Civics (1). Question). The five essay questions were given at cognitive levels 3-5, referring to the revised bloom taxonomy. The instrument grid is presented in table 1 .

Table 1. Instrument Grid

\begin{tabular}{|c|c|c|c|c|}
\hline Subjects & $\begin{array}{c}\text { Basic } \\
\text { Competency }\end{array}$ & Indicator & Level & Description of the Problem \\
\hline PKn & $\begin{array}{l}3.3 \text { Explain the } \\
\text { benefits of the } \\
\text { diversity of } \\
\text { individual } \\
\text { characteristics in } \\
\text { everyday life }\end{array}$ & $\begin{array}{l}\text { students can illustrate the } \\
\text { importance of tolerance } \\
\text { in diversity }\end{array}$ & $\mathrm{C} 4$ & $\begin{array}{l}\text { Presented the incidents of } \\
\text { disputes between community } \\
\text { groups, students illustrated the } \\
\text { importance of tolerance in } \\
\text { responding to these problems. }\end{array}$ \\
\hline Indonesian & $\begin{array}{l}3.6 \text { Exploring the } \\
\text { content and } \\
\text { message of the } \\
\text { poetry presented } \\
\text { orally and in } \\
\text { writing with the } \\
\text { aim of fun. }\end{array}$ & $\begin{array}{l}\text { students can detail the } \\
\text { message / moral message } \\
\text { of a poem }\end{array}$ & $\mathrm{C} 4$ & $\begin{array}{l}\text { Presented a poem, students detail } \\
\text { the message contained in the } \\
\text { poem }\end{array}$ \\
\hline Science & $\begin{array}{l}3.2 \text { Comparing the } \\
\text { life cycles of } \\
\text { several types of } \\
\text { living things and } \\
\text { linking them with } \\
\text { conservation } \\
\text { efforts }\end{array}$ & $\begin{array}{l}\text { students can compare the } \\
\text { life cycle of animals } \\
\text { based on the condition of } \\
\text { the spine (vertebrates- } \\
\text { invertebrates) }\end{array}$ & $\mathrm{C} 5$ & $\begin{array}{l}\text { Presented with a brief description } \\
\text { of worms and snakes, students } \\
\text { compare the two animals' life } \\
\text { cycles. }\end{array}$ \\
\hline Mathematics & $\begin{array}{l}3.6 \text { Determining } \\
\text { the greatest } \\
\text { common factor and } \\
\text { multiples of the } \\
\text { smallest }\end{array}$ & $\begin{array}{l}\text { students can apply FPB } \\
\text { and KPK in everyday life }\end{array}$ & $\mathrm{C} 3$ & $\begin{array}{l}\text { Presented with story questions, } \\
\text { students apply the FPB and KPK } \\
\text { calculations to answer the } \\
\text { problem }\end{array}$ \\
\hline
\end{tabular}




\begin{tabular}{cllll}
\hline Subjects & \multicolumn{1}{c}{$\begin{array}{c}\text { Basic } \\
\text { Competency }\end{array}$} & Indicator & Level & Description of the Problem \\
\hline Mathematics & $\begin{array}{l}\text { commonality with } \\
\text { everyday life } \\
\text { 3.8 Analyze } \\
\text { regular polygon } \\
\text { and irregular } \\
\text { polygon }\end{array}$ & $\begin{array}{l}\text { students can analyze the } \\
\text { characteristics of the } \\
\text { shape of an object }\end{array}$ & $\mathrm{C} 4$ & $\begin{array}{l}\text { Presented a picture of an object } \\
\text { with an irregular plane shape } \\
\text { students analyze the } \\
\text { characteristics of the shape of the } \\
\text { object }\end{array}$ \\
\hline
\end{tabular}

The data that has been collected is analyzed using descriptive statistical analysis. Descriptive statistics are used to find a picture of the core information from the analyzed data set, such as the size of data, data distribution, and the data set. The data test was performed by determining the mean, median, mode, variant, standard deviation, minimum score, and maximum score. While the data analysis technique used to test the research hypothesis is the t-test (polled variance).

The data must meet the prerequisite test to continue to be able to withstand hypothesis testing. The data must fulfil the data: 1) the data to be analyzed must be normally distributed, and 2) the analyzed data must be homogeneous. Testing for normality of data distribution was carried out by using the Chi-Square $\left(\chi^{2}\right)$ test with the criteria, if $\chi^{2}$ count $<\chi^{2}$ table, then the data on the results of students' critical thinking skills in each group were normally distributed. Then the data can be continued with the variance homogeneity test using Fisher's Test with the criteria. If Fcount> Ftable, then the sample data is in a homogeneous state. Furthermore, the hypothesis testing was carried out using the polled variant t-test.

\section{Result and Discussion}

This study's results were divided into two groups of data: the test results of the experimental group's critical thinking ability and the control group. The description of the data analysis results shows that the test results mean score in the thematic learning of the experimental group is higher than the control group $(81.28>65.5)$. The average score of students' critical thinking skills who follow the blended learning station rotation model is better than the average score of students learning with the conventional model.

Furthermore, to test the alleged differences in students' critical thinking abilities between the experimental and control groups, hypothesis testing was carried out. Before testing the hypothesis, the data must meet the data prerequisite test. The data prerequisite test in question is the normality test and the homogeneity test of the data. The normality test of students' critical thinking skills was obtained through the chi-square test. In contrast, the homogeneity test of variance was carried out by using the F-test.

Based on the results of the data normality test with the chi-square test, it is known that at the significance level of $5 \%$ and $\mathrm{db}=2$, the score of the experimental group $\chi^{2}$ count $(0.68)<\chi^{2}$ table $(1.57)$, then the data is normally distributed. Whereas in the control group $\chi^{2}$ hitung $(0.94)<\chi^{2}$ table $(1.57)$, then the data were normally distributed. Furthermore, the results of the variance homogeneity test. The data homogeneity test table Fcount of 2.09 with Ftable score at the 5\% significance level of 4.019. Then, Fcount <Ftable. It means that the variant of thematic learning test results between the experimental and control groups has been homogeneous.

Based on the normality test results, and the homogeneity test, the data is declared to have requirements to proceed to the hypothesis testing. The research hypothesis tested was a significant difference in critical thinking skills between the group of students who took the station rotation blended learning model and the group of students who took the conventional learning model. This hypothesis will be tested through the uncorrelated sample t-test using the polled variance formula. The results of the t-test conducted show that the $\mathrm{t}$ test is 5.21, while the t-table is 2.00 at the $5 \%$ significance level. So, Tcount> Ttable, so that H0 is rejected and $\mathrm{H} 1$ is accepted. The hypothesis test results indicate a significant difference in critical thinking skills between the group of students who take the station rotation type of blended learning model and the group of students who take the conventional learning model. It can be seen from the essay test results on thematic learning carried out in the last meeting with the theme "my dreams."

The test results of the experimental group tended to be better than the control group. The experimental group that was given the station rotation model treatment showed differences in learning attitudes. A positive attitude in learning is meant, such as an increase in thinking activities and patterns formed in response to something. A positive learning attitude will lead to a higher activity intensity than a negative learning attitude (Achdiyat \& Warhamni, 2018). Students who took the blended learning station rotation model showed a very significant increase in learning activities.

Through learning activities that are very dynamic and patterned, making students more active in the learning process. Learning is a combination of human, material, facilities, equipment, and procedures that 
influence each other to achieve goals (Nugraha et al., 2015). The station rotation type of learning model's steps tends to be unique because they encourage students to be active cognitively and physically. Direct experience, which is better known as learning by doing, will give the most complete and meaningful impression regarding the information and ideas. It involves the senses of sight, hearing, touch, smell, and taste. Through the station rotation, students can visit several other stations that provide different information and experiences. It seems fun for students. They can get different learning experiences at each station. Indirectly, students learn many things simultaneously. So that all the material to be achieved in learning can be accommodated more efficiently. Likewise, the responsibility of managing the station itself encourages students to be more active and creative. Students are encouraged to collect and present useful information for friends or other groups of friends in the station rotation model. Given the internet's opportunity, students' enthusiasm was very high more varied content related to the information collected, the more motivating students. In line with (Nugraha, 2020), blended learning can create more varied learning activities. Students can obtain the learning process through teachers and reading books at school, and explore sources on the internet.

The blended learning station rotation can improve information access and convenience, increase learning effectiveness, and increase efficiency. This model's application provides opportunities for students to take advantage of the online digital platform as a source and learning space. Learning through the use of online learning resources can improve students' ability to analyze problems. Haghparast et al. (2014) said, "Student ability to analyze the problem was also could be improved because they try to analyze the problem during online discussion. Furthermore, students indirectly looked for appropriate learning resources to support their understanding". The increased ability to analyze problems is an indication of an increase in students' critical thinking skills.

The important goal of creating easy access to information and learning effectiveness is to activate students' thinking processes. In other cases, the station rotation model's application can also generate multiple interpretations of the various findings in a learning community. This phenomenon was also found in the implementation of learning in the experimental group of students. Differences in information obtained through the internet or other sources and what it finds at different stations stimulate students' curiosity. It will activate the thinking process because there is a disequilibrium in the student's brain. The frequency of students asking questions and giving responses increased. Some students did not hesitate to refute something they thought was wrong or strange. They had encountered at another station. In this special situation, the station rotation type blended learning model seems to have succeeded in stimulating students' thinking processes. His curiosity about the correctness of the information triggered his critical power to grow. According to Hanifah Ameliah \& Munawaroh (2016), an attitude of curiosity includes students' willingness to look for novelty and the desire to find something they have not yet gotten. Reasoning activity that arises from curiosity can encourage critical thinking skills.

Different conditions occur in groups of students who follow conventional learning models. Students tend to be passive, both cognitively and psychomotor. The dominant teacher-centered learning process makes student learning activities tend to be low. There is very limited space for students to explore and express their thoughts in the form of creativity. Teachers are more focused on completing material delivery, not efforts to enrich activities that can stimulate students to learn. The lack of students' opportunities to collect information and investigate something that makes students' thinking activities decrease. As a result, the critical thinking skills of students who follow conventional learning models tend not to be as good as the students' critical thinking abilities in the experimental group.

In addition to increasing thinking activities, applying the station rotation type blended learning model can change students' behavior in managing and concluding information slowly. Students do not immediately digest or use the information they just got. Students tend to want to investigate further truth through a variety of approaches. This pattern is unconsciously formed in the cognitive structure of students when they conclude a fact or information. This phenomenon is concluded based on the findings when students are asked to answer a station's problem. They seem to be active in collecting data through available sources first. Then after being given the opportunity, students always want to review other possible data at different stations. Some students are busy investigating by reading, observing, and asking direct questions. This pattern is a form of critical thinking ability. According to Ennis (2000), one of the ideal aspects of critical thinking skills is the basis for the decision. These aspects include 1) the ability to consider whether the source is reliable or not, and 2) observe and consider an observation result. The facts found in the experimental class indicate that the station rotation type of blended learning model has realized the ideal criterion for critical thinkers, determining the basis for decision making.

Besides that, the students' tendency to discuss was also more visible. In realizing students' critical power through the application of blended learning, students' openness to input information from their peers is very important. No matter how good the information source or learning platform is used, it will not be effective in developing critical thinking skills if it is not accompanied by exchanging ideas/information with other individuals. As stated by Alotaibi (2013) which states "developing critical thinking skills via blended learning is not restricted to various educational tools only, but students should also be perseverant and take the initiative in various discussion situations with other people without fear of being evaluated or criticized. The application of the blended 
learning station rotation type to the experimental group shows the discussion's intensity. Discussions occur intentionally or unintentionally from a small scale to classical. Increasing information and exchanging insights are important assets for developing students' critical thinking skills.

Another aspect that stands out in this research is the increase in skills and awareness to take advantage of technological advances in the learning process. The application of blended learning to the experimental group involves various technology products, software, and hardware. This technology is important because it can be a stimulus for realizing freedom learning or freedom in learning. Students who study using the station rotation type blended learning model gain critical reasoning and positive habits in broadening their horizons through e-learning. However, teachers must understand that students' experiences in accessing technology sources and devices must be different. This difference may lie in the availability and ability to use technological devices, both at home, school, and elsewhere. This has the potential to lead to differences in learning outcomes in the application of blended learning. Jou et al. (2016) said, "different technological preferences and skills amongst students may result in different learning attitudes, atmospheres, and performance. Hence, educators must help eliminate or lower technological barriers experienced by students and instructors during teaching and learning. The right technology must be selected for educational activities to achieve effective teaching and learning".

The use of technology platforms and tools in applying the station rotation type of blended learning needs attention from the teacher. In principle, blended learning can familiarize children with independent learning but still under teachers' and parents' control (Suhartono, 2017). Educators need to anticipate the technological barriers that students experience during the learning process. The right technology must also be chosen to achieve effective teaching and learning. If these points can be realized, the station rotation type blended learning model will run effectively. Thus, being able to develop students' critical thinking skills continuously.

Based on a series of data analysis results, it was found that the ability to think critically between the experimental group and the control group described a significant difference. Students who studied using the station rotation type blended learning model showed a more positive change. The average acquisition of the experimental group students ' critical thinking ability test results is supported by the average acquisition of the experimental group students' critical thinking ability test results, which is much higher than the control group's acquisition. These results align with the research results (Cahyadi \& Probosari, 2012) that the learning process that applies blended learning can improve students' critical thinking skills compared to conventional learning processes. The empirical notes of this study also support these results. Enthusiasm, questioning activities, giving responses, and finding information sources independently of the experimental group students increased dramatically. At the same time, the opposite condition was found in the control group of students. The application of the station rotation type blended learning model is proven to have a positive effect on students' critical thinking skills. This conclusion has implications for applying the station rotation type blended learning suited to students' needs and characteristics, helping overcome students' low critical thinking skills

\section{Conclusion}

Based on the results and discussion, it can be concluded that there is a significant difference in critical thinking skills between groups of students who take the station rotation blended learning model and groups of students who take conventional learning models in thematic learning of fourth-grade students of SDK Karya Singaraja. These results are also reflected in acquisition of average score of critical thinking ability test in thematic learning experimental group, which is higher than control group's average score. It shows that applying the station rotation blended learning model positively affects developing the fourth-grade students' critical thinking skills at SDK Karya Singaraja. It should be understood that not all primary schools in Indonesia are ready to apply this model. It cannot be separated from the availability of facilities such as the internet and computer equipment in schools.

\section{References}

Achdiyat, M., \& Warhamni, S. (2018). Sikap Cara Belajar dan Prestasi belajar. Faktor Jurnal Ilmiah Kependidikan, 5(1), 49-58. https://doi.org/http://dx.doi.org/10.30998/.v5i1.2353

Alotaibi, K. N. R. (2013). The Effect of Blended Learning on Developing Critical Thinking Skills. Education Journal, 2(4), 176. https://doi.org/10.11648/j.edu.20130204.21

Anggraeni, A., Supriana, E., \& Hidayat, A. (2019). Pengaruh Blended Learning terhadap Kemampuan Berpikir 
Kritis Siswa SMA pada Materi Suhu dan Kalor. Jurnal Pendidikan: Teori, Penelitian, Dan Pengembangan, 4(6), 758-763. https://doi.org/10.17977/jptpp.v4i6.12505

Banggur, M. D. V., Situmorang, R., \& Rusmono, R. (2018). Pengembangan Pembelajaran Berbasis Blended Learning Pada Mata Pelajaran Etimologi Multimedia. JTP - Jurnal Teknologi Pendidikan, 20(2), 152165. https://doi.org/10.21009/jtp.v20i2.8629

Blankson, L., Kyei, \& Ntuli, E. (2014). Practical Aplication And Experience In K-20 Blended Learning Environment. United State of America: IGI Global.

Burhaein, E. (2017). Aktivitas Fisik Olahraga untuk Pertumbuhan dan Perkembangan Siswa SD. Indonesian Journal of Primary Education, 1(1), 51. https://doi.org/10.17509/ijpe.v1i1.7497

Cahyadi, F. D., \& Probosari, R. M. (2012). Penerapan Blended Learning Dalam Pembelajaran Biologi Untuk Meningkatkan Kemampuan Berpikir Kritis Siswa Kelas Xi Ipa 4 Putra SMA RSBI Pondok Pesantren Modern Islam Assalaam Sukoharjo. Pendidikan Biologi, 4(1), 15-22.

Crismono, P. C. (2017). Pengaruh Outdoor Learning Terhadap Kemampuan Berpikir Kritis Matematis Siswa The Influence Of Outdoor Learning On The Mathematical Critical Thinking Skills Of Students. Junal Pendidikan Matematika Dan Sains, 4 106-113. https://doi.org/https://doi.org/10.21831/jpms.v5i2.15482

Drysdale, J. S., Graham, C. R., Spring, K. J., \& Halverson, L. R. (2013). An analysis of research trends in dissertations and theses studying blended learning. The Internet and Higher Education, 17, 90-100. https://doi.org/10.1016/j.iheduc.2012.11.003

Haghparast, M., Nasaruddin, F. H., \& Abdullah, N. (2014). Cultivating Critical Thinking Through E-learning Environment and Tools: A Review. Procedia - Social and Behavioral Sciences, 129, 527-535. https://doi.org/10.1016/j.sbspro.2014.03.710

Hanifah Ameliah, I., \& Munawaroh, M. (2016). Pengaruh Keingintahuan Dan Rasa Percaya Diri Siswa Terhadap Hasil Belajar Matematika Kelas Vii Mts Negeri I Kota Cirebon. Eduma: Mathematics Education Learning and Teaching, 5(1), 9-21. https://doi.org/10.24235/eduma.v5i1.598

Jaya, H. N. (2017). Keterampilan Dasar Guru untuk Menciptakan Suasana Belajar yang Menyenangkan. Jurnal Pendidikan Dan Ilmu Pengetahuan, $23-35$. http://103.114.35.30/index.php/didaktis/article/view/1555/1275

Jou, M., Lin, Y.-T., \& Wu, D.-W. (2016). Effect of a blended learning environment on student critical thinking and knowledge transformation. Interactive Learning Environments, 24(6), 1131-1147. https://doi.org/10.1080/10494820.2014.961485

Jupriyanto. (2018). Kemampuan Berpikir Kritis Siswa Dalam Pembelajaran Ilmu Pengetahuan Alam Kelas Iv. Jurnal Ilmiah Pendidikan Dasar, 5(2), 105. https://doi.org/10.30659/pendas.5.2.105-111

Mabruroh, F., \& Suhandi, A. (2017). Construction Of Critical Thinking Skills Test Instrument Related The Concept On Sound Wave. Journal of Physics: Conference Series, 812, 012056. https://doi.org/10.1088/1742-6596/812/1/012056

Marfilinda, R., Fitria, Y., \& Marsidin, S. (2019). Pengaruh Model Learning Cycle 7 E Dan Pengetahuan Awal Terhadap Keterampilan Berpikir Kritis Siswa Pada Pembelajaran Ipa Di Kelas V Sd. Jurnal Ilmiah Pendidikan Dasar, 6(2), 84. https://doi.org/10.30659/pendas.6.2.84-97

Ningsih, Y. L., Misdalina, M., \& Marhamah, M. (2017). Peningkatan Hasil Belajar dan Kemandirian Belajar Metode Statistika Melalui Pembelajaran Blended Learning. Al-Jabar : Jurnal Pendidikan Matematika, 8(2), 155. https://doi.org/10.24042/ajpm.v8i2.1633

Novia Anggraini, Wayan Suana, F. S. (2018). Pengaruh Penerapan Blended Learning Berbasis. Jurnal Tarbawi : Jurnal Ilmu Pendidikan, 3(02), 85-93.

Nugraha, D. M. D. P. (2020). Integrasi Pendidikan Karakter Dalam Penerapan Blended Learning Di Sekolah Dasar. Cetta: Jurnal Ilmu Pendidikan, 3(3), 472-484.

Nugraha, D. M. D. P., Prof. Dr. Anak Agung Gede Agung, M. P., \& Dra. Ni Nengah Madri Antari, M. E. (2015). Pengaruh Model Pembelajaran Self Regulated Learning ( Srl ) Terhadap Sikap Ilmiah Dan Hasil Belajar Ipa Siswa Kelas IV. Journal PGSD Universitas Pendidikan Ganesha, 3(1). https://doi.org/10.23887/jjpgsd.v3i1.5664 
Prescott, J. E., Bundschuh, K., Kazakoff, E. R., \& Macaruso, P. (2018). Elementary school-wide implementation of a blended learning program for reading intervention. The Journal of Educational Research, 111(4), 497-506. https://doi.org/10.1080/00220671.2017.1302914

Rusnah, R., \& Mulya, O. T. (2018). Meningkatkan Keterampilan Berpikir Kritis Siswa Melalui Pendekatan Saintifik Di Sekolah Dasar. Jurnal Gentala Pendidikan Dasar, 3(2), 239-256. https://doi.org/10.22437/gentala.v3i2.6760

Setyaningsih, T. D., Agoestanto, A., \& Kurniasih, A. W. (2014). Identifikasi Tahap Berpikir Kritis Siswa Menggunakan PBL dalam Tugas Pengajuan Masalah Matematika. Kreano: Jurnal Matematika KreatifInovatif, 5(2), 180-187. https://doi.org/10.15294/kreano.v5i2.4544

Simanjuntak, M. F., \& Sudibjo, N. (2019). Kemampuan Memecahkan Masalah Siswa melalui Pembelajaran Berbasis Masalah. Journal of Holistic Mathematics Education, 2(2), 108-118. https://doi.org/https://dx.doi.org/10.19166/johme.v2i2.1331

Suartama, I. K. \& I. D. K. T. (2014). ELearning Berbasis Moodle. Graha Ilmu.

Sugiono. (2015). Penelitian Pendidikan (Pendekatan Kuantitatif, Kualitatif, dan R\&D). Alfabeta.

Suhartono. (2017). Menggagas Penerapan Pendekatan Blended Learning Di Sekolah Dasar.

Surya, H. (2011). Strategi Jitu Mencapai Kesuksesan Belajar. Jakarta: PT Elek Media Komputindo. PT Elek Media Komputindo.

Susanto, A. (2015). Teori Belajar dan Pembelajaran di Sekolah Dasar. Prenadamedia Group.

Syarif, I. (2013). Pengaruh model blended learning terhadap motivasi dan prestasi belajar siswa SMK. Jurnal Pendidikan Vokasi, 2(2), 234-249. https://doi.org/10.21831/jpv.v2i2.1034

Syarifah, S., \& Sumardi, Y. (2015). Pengembangan Model Pembelajaran Malcolm'S Modeling Untuk Meningkatkan Keterampilan Berpikir Kritis Dan Motivasi Belajar Siswa. Jurnal Inovasi Pendidikan IPA, 1(2), 237. https://doi.org/10.21831/jipi.v1i2.7510

Usman, U. (2019). Komunikasi Pendidikan Berbasis Blended Learning Dalam Membentuk Kemandirian Belajar. Jurnal Jurnalisa, 4(1), 136-150. https://doi.org/10.24252/jurnalisa.v4i1.5626

Widyaningsih, O., Yudha, C. B., \& Nugraheny, D. C. (2020). Pengembangan Model Blended Learning untuk Sekolah Dasar. Jurnal Pendidikan $143-156$. https://doi.org/https://doi.org/10.21009/10.21009/JPD.081 